\title{
Challenges and Opportunities for North American Hardwood Manufacturers to Adopt Customization Strategies in an Era of Increased Competition
}

\author{
David L. Nicholls ${ }^{1, *}$ and Matthew S. Bumgardner ${ }^{2}$ \\ 1 Research Forest Products Technologist, Pacific Northwest Research Station, Sitka, AK 99835, USA \\ 2 Research Forest Products Technologist, Northern Research Station, Delaware, OH 43015, USA; \\ mbumgardner@fs.fed.us \\ * Correspondence: dlnicholls@fs.fed.us; Tel.: +907-738-2176
}

Received: 1 March 2018; Accepted: 3 April 2018; Published: 5 April 2018

\begin{abstract}
Much of the North American wood products industry was severely impacted by the recession of 2008-2009. In addition, many sectors within this industry face intense global competition. Against this backdrop, we examine economic opportunities for hardwood manufacturers to achieve greater competitive advantage via product customization, through a literature review and synthesis. We also discuss several related themes including agility, lean manufacturing, and clustering. We found that, in globally competitive environments, hardwood producers must be agile to adapt to economic conditions and dynamic customer demand. We discuss how some sectors of the hardwood industry have effectively exhibited customized production, and subsequently fared relatively well in the current economy. We conclude the synthesis by evaluating the importance of supply chains to achieving customization for hardwood producers. In the future, supply chains will need to be configured to rapidly respond to changing consumer demands, and pressure to provide more services will likely extend further back up the supply chain to hardwood sawmills. It is expected that sustainability practices, including green supply chain management, will impact operational and economic performance of hardwood firms as well.
\end{abstract}

Keywords: customization; competitive advantage; lean; agile; supply chain; hardwood products

\section{Introduction}

\subsection{The Hardwood Value Chain: From Forest to Consumer}

Competition among firms is dynamic and is closely related to innovation and the search for strategic differences, according to Porter [1]. Competition is also pervasive, whether it involves companies contesting markets, countries coping with globalization, or organizations responding to societal needs. Directly related to competition is the creation of customer value, or delivering a desired product at an acceptable price. Although value may not have a consistent universal meaning, it is clear that the process of delivering value to consumers is becoming the imperative for many organizations-in the wood products sector and elsewhere. Therefore, the importance of understanding competition and value creation is often a prerequisite for business success. It is within this context that the present review synthesizes literature pertaining to the increasing role that customization plays in the North American hardwood industry, especially in secondary sectors such as furniture and cabinets.

Hardwood forests are noted for their ecological diversity, containing numerous commercial species. Forest economics plays an overriding role in aspects of forest regeneration, silviculture, harvest, transportation, manufacture, distribution, product use, and ultimately recycling. The hardwood species 
mix preferred by consumers is dynamic, requiring manufacturers to stay abreast of not only current forest and economic conditions but also consumer preferences. Although the focus of this paper relates to the competitiveness of the North American secondary hardwood industry, an overarching theme is the role of the complete forest value chain. This includes all "upstream" value-chain entities, including forest landowners, managers, harvesters, and manufacturers of primary products such as lumber and veneer. These upstream entities are especially integral, as forest management and sawmill decisions can influence the appearance characteristics and value of primary hardwood products used as inputs to secondary manufacturing [2,3]. In addition, "downstream" customers, and ultimately consumers, are increasingly important to the hardwood supply chain.

The North American hardwood industry faces new challenges in dynamic international markets. This sector now must compete with global supplies of raw materials and global manufacturers for U.S. consumers. The recent loss of manufacturing infrastructure for some components of the North American industry has brought high levels of change and uncertainty. Of greatest importance and concern is the ability to competitively manufacture and maintain supply chains, while providing stability to other sectors of the overall forest industry [4]. In addition, repercussions of the housing crisis are still being felt today across many wood product sectors, which has cast new emphasis on the way firms do business and interact with others in their supply chains. For example, the size of the average U.S. secondary manufacturer had not fully returned to pre-recession levels by 2015, but the trend was upward and secondary manufacturers were requiring increasing services from their hardwood lumber suppliers [5]. Thus, we emphasize current economic events in our synthesis as well as the markets served, which are increasingly global in nature.

\subsection{Mass Customization-A Paradigm Shift for the Wood Products Industry}

For wood products industries to realize competitive advantage, they must identify competitive strengths at all points in the value chain. This was especially evident during the recent U.S. housing crisis. Panwar et al. [6] recount the relevant macroeconomic factors and resulting dislocations felt by domestic wood products firms during the 2008 recession, identifying specific actions that could help maintain competitive advantage throughout the forest sector supply chain during periods of economic crisis. Firms that successfully adapted to decreased demands, fluctuating prices and exchange rates, and greater competition were better able to survive the recession. They also identified strategies for maintaining coherent and intact supply chains during times of financial crisis.

Optimum strategies for maintaining and enhancing competitive advantage are constantly evolving-what worked well in the most recent business cycle may not be as effective in the future, especially during economic downturns. Brown and Blackmon [7] introduced the concept of strategic resonance and strategic dissonance to compete within highly volatile markets. They discuss two ways that firms can gain competitive advantage. A market-led view suggests that the key is to identify external opportunities in both new and current markets (including niche markets). By contrast, a resource-based view argues that firms should mobilize resources that are likely to maximize returns in their chosen markets. Here, competitive advantage is realized by the valuable firm-level resources that competitors do not have access to. Competitive strategies must then be based on approaches that consider both market requirements and manufacturing capabilities under dynamic and unpredictable business environments. New production paradigms, such as mass customization, can increase this flexibility for secondary hardwood manufacturing firms, and this has become a frontier issue for the industry.

It has been said that mass customization is a complete paradigm shift from traditional manufacturing [8]. In North America, Europe, and other regions with high labor and land costs such as Singapore and Hong Kong, much research has looked at mass customization, lean manufacturing, strategic supply chains, and other strategies for maintaining or enhancing manufacturing competitiveness [9]. In the U.S. wood products industry, a paradigm shift has been called for in sectors especially affected by globalization. One such sector is the wood household 
furniture industry $[10,11]$, where customized production and strategic supply chain alliances are key elements of competitiveness. Similarly, Dugan [12] has called for several "new rules" for the U.S. furniture industry, including agility, niche marketing, supply chain development, and lean production. Azouzi et al. [13] claim that competitive priorities for the furniture enterprise of the future are short lead times, high product quality, product variety and innovativeness, and a focus on profit margin. A key component of a paradigm shift is the desire of consumers for customized products [14]. Thus, by leveraging this demand with development of customized production, the U.S.-based industry can be more competitive. Shortening the lead times associated with customization is a key component of competitiveness, and as will be discussed in this synthesis, can be enhanced through factors such as lean manufacturing, supply chain agility, and local sourcing/purchasing of goods.

Mass customization has been defined as production of individually customized products using flexible and responsive manufacturing systems at a cost and speed near that of mass-produced items $[8,13]$. The potential advantage lies in realizing price premiums for products customized to customers' specific demands, while at the same time maintaining the cost associated with large-scale production [9]. Gilmore and Pine [15] posit that consumers are increasingly moving away from a mindset of settling for standardization (and thus forgoing their individuality) simply to achieve a lower price, thus creating "customer sacrifice gaps". This is a frontier provision where producers in higher-cost locations can compete, by moving away from price and towards provision of customized goods [16]. Previous studies have shown that consumers are willing to pay more for customized products [17].

Successful implementation of mass customization in the hardwood products industry has broad-reaching economic ramifications throughout the forest value chain. This includes not only manufacturing, but also product sourcing, procurement, and even harvesting and silvicultural methods, which can influence wood quality and/or product quality. For example, alignment between forest owners, logging contractors, and wood products manufacturers was identified as a key element of entrepreneurial success, which included the presence of strong networks [18]. Customization is therefore on the "frontier" of research and practice for the hardwood industry and will be the focus of this review and synthesis. We discuss some of the most central, state-of-the-art, and recent research involving customization and related concepts and how they are being applied in the North American hardwood industry. The end result, if this frontier can be successfully expanded, is more efficient production of the market goods derived from hardwood forests.

\section{Methods and Objective}

In this review and synthesis, the objective was to discuss the literature regarding mass customization, including the related concepts of agility, lean manufacturing, economic clustering, and supply chain management with the intent to find linkages to competitiveness for the North American hardwood industry. While the entire hardwood supply chain is considered, the focus was on secondary manufacturers. We utilize a combination of articles that specifically address the forest products industry, as well as more general articles. The primary source of articles was a search carried out using Google Scholar in the summer of 2017 based on the following key words: customization, competitiveness, competitive advantage, lean, clusters, agile, and supply chain. The qualifying words of wood products and hardwood also were used to focus on articles specific to the secondary wood products industry. Initially, 94 of the articles discovered in this fashion were pre-screened as potentially relevant to the synthesis and sought for analysis. In addition, other articles were found through cross-referencing the articles identified in the Google Scholar search, or included via knowledge of the authors. This led to the inclusion of other relevant articles not identified through the primary search. The body of research in these fields is quite expansive; for example, Mishra et al. [16] provide a recent review of 118 articles related to manufacturing flexibility alone, while Bhamu and Sangwan [19] recently reviewed 270 articles related to lean manufacturing. A goal of this work therefore was not to provide an exhaustive list but rather to weave a subset of these papers together, combining them with 
work specific to forest products, to provide a practical discussion. A total of 87 articles ultimately were referenced in this synthesis, with over $43 \%$ being published since 2010 . While the synthesis did not consider a specific time frame, preference was given to more recent studies since the focus was on the "frontier" of the field.

The following sections discuss customization and its relationships with the related concepts outlined above. Linkages between these concepts and competitiveness are discussed. The paper concludes with a discussion of the frontier of customization research with regard to the hardwood industry supply chain, focusing on the secondary wood products industry.

\section{Discussion}

\subsection{Agility and Customization}

Agility has been said to go "hand in hand" with mass customization [20] while other authors have claimed it is a related but different construct [19]. For example, Um [21] claims that agility is constrained by a parallel focus on economies of scale in many industries where efficiency is the focus, but that supply chain agility is requisite in high-level customization environments such as production of innovative or fashion products with short lifecycles. Stump and Badurdeen [8] refer to agility as responsive manufacturing in unpredictable environments, without specific reference to customizing for individual customers. However, in their extensive review of mass customization research, Fogliatto et al. [17] found that a common feature of the literature is a blurring of mass customization, lean, and agile concepts. They conclude that both lean and agile concepts are relevant to implementation of mass customization and they call for more research aimed at elucidating these linkages.

According to Azouzi et al. [20], agility is "... the ability to respond to, and create new windows of opportunities in a turbulent market environment driven by individualizing customer requirements cost effectively". Similarly, Um [21] claims that agility refers to a firm's capability to " ... transform market uncertainty into opportunities through rapid response, especially in high-level customization environments". Routroy and Shankar [22] evaluated agile supply chains, finding that they can be effective at functioning in challenging markets such as those characterized by uncertain demand, new and/or innovative products, and dynamic customer expectations. They developed a methodology known as "performance value analysis" to evaluate agile supply chains along three different time horizons for apparel supply chains, finding that significant performance improvements in supply chains could be realized in as little as two years.

Agility has been said to be enabled by the introduction of new technology, which is driven by market interaction and product design $[13,20]$. To these authors, a given process best contributes to the agility of a manufacturing enterprise when it possesses several capabilities, including flexibility, responsiveness, and autonomy. The result is the "furniture enterprise of the future" where the technology employed matches the customization strategy of the firm. The furniture enterprise of the future seems consistent in many ways with the paradigm shift described by Schuler and Buehlmann [11] and the new rules for the industry described by Dugan [12].

A note should be made on the distinction between flexibility and agility, even though these terms often are used interchangeably in the literature to refer to responsiveness to changes in the business environment. For example, Azouzi et al. [13] claim that flexibility is a subset of agility, referring specifically to the ability for a process to outlive the products for which it was originally built. Regardless of the definitional refinement, agility and flexibility are important in light of an increasingly global and customized economy, and the plurality of research on flexibility has focused on its relationship to environmental uncertainty [16]. In the wood products industry, the importance of upstream suppliers to think strategically about the competitiveness of their downstream customers in the midst of uncertainty over globalization (i.e., the loss of the furniture industry as a market for hardwood lumber) has also been discussed [23]. 
Comparative studies of the U.S. furniture and cabinet industries have shown that agility and customization strategies are associated with competitiveness. For example, Lihra et al. [24] found that, when studying these industries in North America and Europe, the cabinet industry scored highest for implementation of mass customization while the household furniture industry scored lowest. The upholstered and office furniture sectors scored between the other two. Cumbo et al. [25] likewise found that the cabinet and upholstered furniture industries were implementing lean manufacturing at a higher rate than other sectors. And, Lihra et al. [24] found that the cabinet, upholstery, and office furniture sectors were following an assemble to order production model (more customized), while household furniture was following a ship to order model (less customized). This is consistent with the findings of Luppold and Bumgardner [26] that the U.S. cabinet industry carried less inventory, offered more customized products, and competed less on price than did the U.S. wood household furniture industry. These factors were enabling the cabinet industry to be more competitive than the wood household furniture industry.

Import market shares are a useful way to analyze the competitive positions of different U.S. wood products industries [27]. Figure 1 shows estimated market share statistics for three sectors for the latest year data were available. It can be seen that the wood kitchen cabinet industry (NAICS 337110) has been less affected by globalization to date than the nonupholstered wood household furniture (NAICS 337122) and upholstered furniture (NAICS 337121) sectors-a finding consistent with the comparative studies discussed above. In turn, the upholstered furniture sector (which has been the subject of several lean manufacturing studies) has been less affected by globalization than the wood household furniture sector. This notion of relative industry competitiveness will be revisited in the clustering section that describes how sectors of the furniture industry that customize products (similar to the cabinet industry) have realized success in the United States.

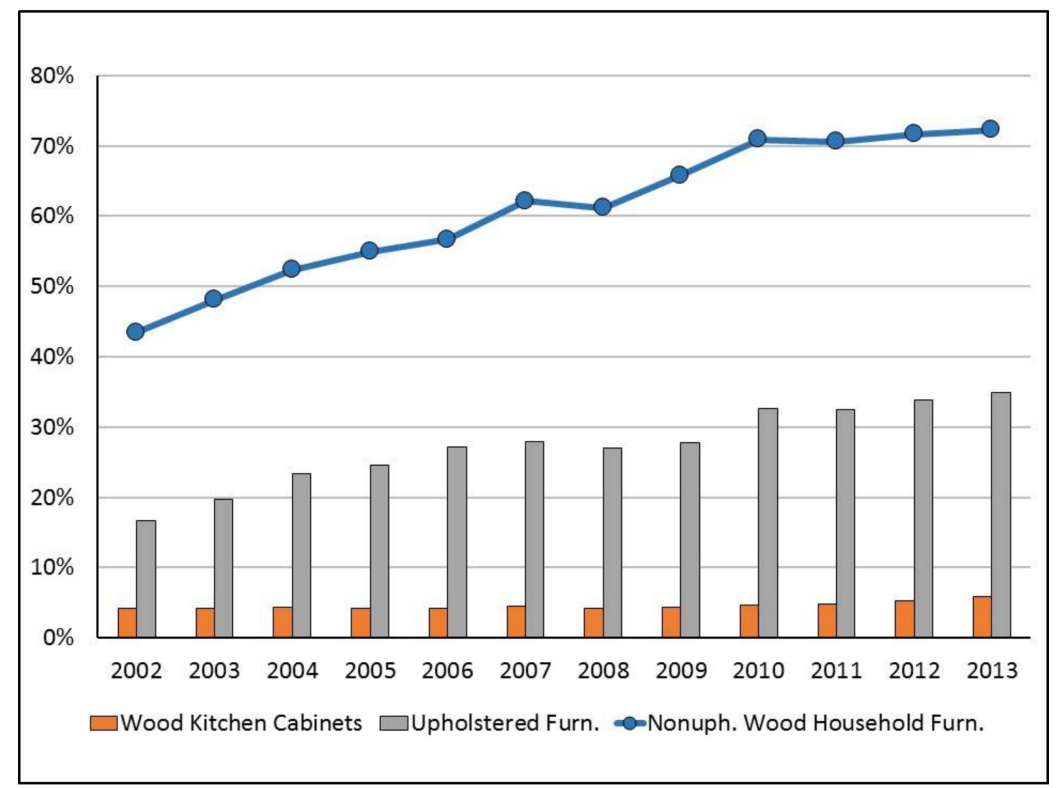

Figure 1. Estimated import market shares in the wood household furniture, upholstered furniture, and kitchen cabinet sectors in the United States. Import market shares in the United States calculated as: Imports/Consumption, where: Consumption = Value of product shipments (Production) + Imports - Exports (Data sources: [28-30]).

\subsection{Lean Manufacturing and Customization-The Skinny on Wood Value Chains}

Lean refers to far more than just dieting. Lean manufacturing is generally described as a production system that uses fewer resources than mass production systems (for example less labor, equipment, and space), while achieving superior results. In fact, lean producers often aim for 
perfection [31], leading to declining costs, almost zero defects and inventories, and greater product variety [32]. Others have defined lean production as "an integrated socio-technical system whose main objective is to eliminate waste by concurrently reducing or minimizing supplier, customer, and internal variability" [33], although variance reduction also is associated with related concepts such as six-sigma.

Returning to the cabinet industry discussion from the previous section, less inventory is often needed using lean manufacturing as a competitive strategy. However, mass customization has been said to be incompatible with lean manufacturing $[8,21]$. For example, mass customization follows a "design-sell-make" model where the final product is not manufactured until the end-consumer order is received. In lean manufacturing, items are made to meet the needs of immediate customers (i.e., intermediate to the end-consumer in the supply chain) and not the end-consumers themselves. Olhager and Prajogo [34] explored potential differences between "make-to-order" and "make-to-stock" firms in Australia. After considering 216 firms, they found that make-to-order firms benefit significantly from supplier integration, whereas make-to-stock firms benefit significantly from lean practices. These findings indicate that the difference between these models is important when considering potential manufacturing and supply chain improvements.

Nag et al. [35] consider the influence of inventory management on the competitive position of manufacturing firms. They identify three stages of inventory-raw material, work-in-process, and finished goods - the management of which can influence a firm's competitive position. The authors follow Porter's "Five Forces Model", analyzing factors driving supply chain strategies, including: industry intensity of rivalry, threat of new entrants, threat of substitutes, bargaining power of suppliers, and bargaining power of buyers. They found that this framework can influence whether an industry shows low versus high levels of raw material inventories and finished goods inventories. Inventory management also can greatly influence how supply chains are configured. Stavrulaki and Davis [36] identify four different supply chain structures: make to stock, assemble to order, built to order, and design to order, where various structures are best suited to different combinations of products and demand characteristics. A key finding of this study was that high-volume products with little uncertainty about their demand should be matched with lean supply chains enabled by efficient processes. Conversely, low-volume, high-uncertainty products should be matched with agile supply chains enabled by flexible processes.

In the wood products industry, Cumbo et al. [25] found that implementing lean manufacturing might not be applied evenly across the facility. In particular, the rough mill, where lumber is converted to parts for later assembly, was less likely to be lean than other parts of the facility. Ray et al. [37] found that primary wood products manufacturers are inherently leaner than secondary manufacturers and suggest that not all classical lean metrics are entirely relevant to wood products manufacturers. Haartveit et al. [38] explored supply chain management in the forest products industry of western Canada; successful implementation of supply chain improvements were found to focus on efficiencies through increasing throughput and reducing inventories. However, it was found to be challenging to apply supply chain management techniques to commodity-based supply chains such as wood products producers. This was primarily due to uncertainty in raw material supply and relatively long lead times in production.

Other authors have claimed that lean manufacturing can help enable mass customization. According to Bhamu and Sangwan [19], "The goal of lean manufacturing is to be highly responsive to customer demand by reducing waste". According to these authors, product variety and the integration of product development with supply chain and operations management are some of the goals for which lean manufacturing is implemented. Modern definitions of lean production state in part that it provides companies with the agility to face market demands and environmental changes [39]. Several of the definitions of lean manufacturing found in the literature reference the provision of product variety that can be achieved through lean production [19].

The advent of computer optimization has made concepts such as dynamic prioritization strategies feasible. In such systems, emphasis is placed on different part sizes as part needs are met and different 
lumber grades and sizes are used [40]. However, Cumbo et al. [25] found that yield of parts was the primary performance metric even though maximizing yield did not necessarily mean high-demand parts were being produced. Pirraglia et al. [41] also suggest that customer-driven inventory practices could result in yield losses (i.e., disposal of clear wood) in wood products companies. However, movement toward lean principles was associated with several customer satisfaction variables, suggesting multiple potential benefits to lean manufacturing beyond cost reduction. Czabke et al. [42] found similarly that, even though most benefits were manufacturing-related, implementation of lean thinking allowed manufacturers to get closer to their customers and could even pave the way for implementation of mass customization programs. In the case study presented by Czabke et al. [42], this was believed by the company to have led to competitive advantage. Ariss and Zhang [43] discussed the notion of "flexible process capability" and found evidence that it was possible for firms, through flexible technology and employee involvement, to achieve high product variety while maintaining low process variety, essentially achieving mass customization. Buehlmann et al. [44] discuss the role that the digitization of manufacturing likely will play in the future of the hardwood industry and in helping to enable lean and agile manufacturing.

In the wood products industry, implementation of lean manufacturing has been associated with shorter lead times, with an average 10-day shorter lead time for lean companies [25] as well as greener production [45]. Time to market is an important component of mass customization [9], so lean practices seemingly can help here. Stump and Badurdeen [8] discuss "job shop lean" as a system where certain lean practices, such as value stream mapping, are applied to small firm customized environments. Given the small size of many firms in the secondary wood products industry [46], this concept seems well-suited to the industry, although literature to date on actual application is limited. Others have noted that implementing lean is more difficult in smaller firms for a variety of reasons, including use of the wrong lean tools, use of a single tool to fix all problems, lack of understanding, and overall lack of financial and management resources [19].

One potential compromise that has been found between lean manufacturing and customization, is determining an optimal lot size. Yao and Carlson [47] found that, for a large upholstered furniture company with many possible product design combinations, a small lot size of 15 units per batch was the key to balanced and synchronized production. Coupled with an on-line, real-time data capture system that tracks status and location of materials in each batch, this was a way to link agility with leanness and realize competitiveness. Other authors have noted the importance of using information systems to collaborate with consumers to obtain their design and preferences for customized products $[13,17]$ and in monitoring supply chain performance measures [48]. However, Hunter et al. [49] noted that batch and queue operations are outdated and based on a system of material movement through distinct departments within a shop where each worker is assigned to a single process or workstation. They instead argue for a system based on manufacturing cells, where each cell contains multiple functions and has the ability to produce a wide variety of products at low cost (i.e., economy of scope) and permits rapid design changes for upholstered furniture customers.

Manufacturing has been defined by Hunter et al. [49] as " ... the creation of wealth by adding value to raw materials". This notion is at the core of searching for successful competitive strategies for the forest products industry. However, while much research has been conducted on the product side of mass customization, much less has been published concerning the manufacturing costs [17]. In the forest products literature, product costing was addressed by Andersch et al. [50], who found that 74 percent of the companies surveyed relied on traditional accounting systems that failed to account for many of the costs associated with lean and/or mass customization activities (product diversity, operational complexity, etc.). Additional economic analysis of cost drivers would therefore seem to be an important area for future research. 


\subsection{Economic Clustering and Customization}

Clusters can be defined as "... geographic concentrations of interconnected companies and institutions in a particular field" [51]. Clusters may be thought of in two dimensions as they can extend downstream to customers, and also laterally to manufacturers of complementary or related products. Clustering can also serve as a means for small companies to realize some of the economies of scale usually reserved only for large companies [52]. Clusters of forest products companies can exhibit competitiveness and there are several examples of success [53,54]. Walcott [55], and Kodzi and Gazo [56] discuss that the history of furniture manufacturing in the United States has followed a regional clustering pattern over time, with new formations in regions with lower-cost factors of production. The extension to global manufacturing also follows this pattern, with movement to Taiwan and later China [57]. More recently Vietnam has emerged as a low-cost manufacturer of household furniture for the global market and it also has benefitted from U.S. duties on some Chinese wood furniture [58].

One example of a paradigm shift in the U.S. industry is Amish furniture manufacturing in Ohio and elsewhere. Unlike the other regional U.S. furniture clusters described above where costs ultimately drove change, the Ohio Amish cluster formed through a sense of embeddedness in the community [59] where important motivation for firms is to remain a viable family-based shop and continue living in the area [60]. In this cluster, competitiveness arises by other means based largely on a customization model. The clustering aspects that enable customization include specialization among the many small shops and well-defined supply chains that allow flexibility among several shops [51]. For example, Brookfield [61] found that firms operating within clusters outsource inputs to a greater degree than do non-clustered firms, in essence forming a "system of network production". A good example of how such a production system can work is in the aggregate productivity of the cluster. Even though the firms are quite small on average, their input productivity (wood use per employee) was found to be quite similar to the broader U.S. furniture industry when factoring in the firms specializing in component manufacturing [60].

Buehlmann and Schuler [57] make a connection between local markets, mass customization, and competitiveness; the customer/producer interface and short lead times necessary for mass customization give local and regional producers inherent advantages over importers, citing the U.S. architectural millwork industry as an example. Similar observations have been discussed for the furniture industry (especially upholstery) in the United States by Walcott [55], who added logistics considerations as a key factor to regional competitiveness. Others also have noted the potential value of buyer-supplier proximity in developing lean supply chains [62]. Maskell [63] describes a successful wood furniture cluster in Denmark where competitiveness was attributed to the ease of communication and exchange of knowledge arising from the close proximity of producers.

The Amish furniture cluster model follows what Stump and Badurdeen [8] refer to as low-level mass customization, whereby consumers are involved in the assembly decisions for their products but design and fabrication are more modular. Multiple choices in species, finish, and hardware are offered at the retail level and consumer orders are then placed with local manufacturers [60]. There are now even options for the type of wood to be used, i.e., whether or not to use character-marked or naturally blemished woods, with a price differential. This practice is consistent with the findings of Brinberg et al. [64] and Bumgardner et al. [65] that the best opportunities for greater use of character-marked wood might be realized by manufacturers and consumers working together directly to design the product. Increased use of character-marked wood has long been sought as a means to more efficiently use harvested timber [66], but proven difficult to implement in traditional (i.e., non-customized) furniture marketing systems [67].

In essence, consumers are participating in the design stage of furniture manufacture in the system described above [15]. Jensen et al. [68] report a similar situation in the Swedish construction industry, where modularization was found to be a bridge between mass production of standardized prefabricated components and being able to meet customers' increasing requirements for customization in multi-story 
timber housing. In the system described, Jensen et al. [68] explain how the design phase of the construction project was replaced by a configuration phase. Hock Soon and Udin [69] found similarly that organizations could enhance manufacturing flexibility by creating supply and logistics networks that were highly responsive to customers. Christensen et al. [70] also evaluated the role of customers in supply chain regimes, comparing build-to-order and just-in-time management. They found that build-to-order strategies can positively influence market performance through a greater supply chain knowledge with customers (i.e., a downstream application). Conversely, just-in-time strategies affect upstream application of knowledge with suppliers.

In fact, this is a similar model followed in the U.S. cabinet industry, which as described previously, has been more competitive than the wood household furniture industry [24,26]. Consumers can choose from a variety of styles, species, and finishes, and the final product is then transported to where it is needed [15], in this case, cabinets delivered to the point of installation. In such systems, lean manufacturing concepts fit well in that single pull signals for standardized components are used in downstream assembly [8]. Jiao et al. [9] describe a similar concept in terms of "reusability" of design and process capabilities thereby creating underlying product architecture from which customized products can then be derived.

\subsection{Pulling Everything Together with Supply Chains-At the Frontier of Customization}

A basic hardwood product value chain includes key elements from stump to consumer, including trees, sawmills, distributers, secondary manufacturers, and ultimately, end users (Figure 2). Value chains help visualize the flow of manufacturing from raw material to final product by showing the steps where value is added [71]. It has been said that: "The value chain has become the focal point of mass customization competition" [17]. Indeed, Um [21] states that the ultimate aim of supply chain management is to reduce costs and improve customer service, which at the base level are the two primary tenets of mass customization. Maintaining consistent, reliable, and economical supply chains that are also manageable is one of the leading challenges for hardwood manufacturers. This is in part due to a multitude of product parts, manufacturing methods, harvesting stages, and transportation networks, as well as the design and fashion aspects associated with dynamic consumer tastes for many hardwood products. In recent years, global competition also has greatly changed the way that hardwood producers approach supply chain decision making.

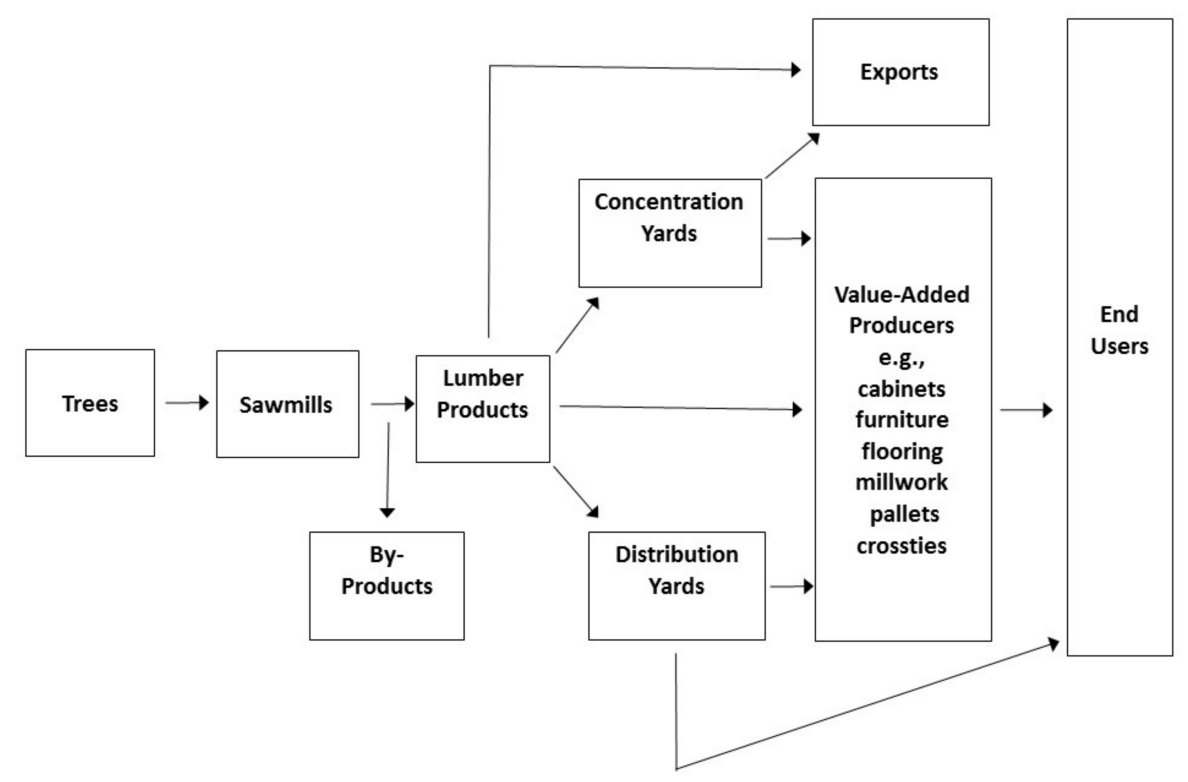

Figure 2. Basic value chain for North American hardwood product manufacturing (adapted from Cohen and Kozak [71]). 
Li et al. [72] conceptualized 5 aspects of supply chain management, and collected data from 196 firms and tested the effects on organizational performance. They found that higher levels of supply chain management practice can lead to enhanced competitive advantage and improved organizational performance. The five supply chain aspects were: strategic supplier partnerships (e.g., long-term relationships needed between organization/manufacturer and suppliers), customer relationships (e.g., practices to enhance long-term relationships with customers), level of information sharing (e.g., critical/proprietary information communicated to supply chain partners), the quality of information sharing (e.g., accuracy, timeliness, and credibility of information), and postponement (e.g., moving operations or activities to later points in the supply chain). Kipserska-Moron and Swierczek [73] introduce the concept of postponement with respect to modern supply chains. Using an international survey approach, they found that dynamic supply chains can undergo reconfigurations, and that this is in response to increased demand for customized products. They also found that a "full postponement strategy" is possible but depends on the level of product customization as well as a firms' manufacturing and logistical capabilities.

Supply chains also are becoming longer and more complex due to globalization [74,75]. This can further complicate the already complex nature of hardwood supply chains [76,77]. Therefore, logistics management and supply chain tuning become key to remaining flexible in a high customization environment [74]. Bozarth et al. [78] modelled the complexity of international supply chains and provided empirical tests from 209 plants in seven countries. They considered both detail complexity (the distinct number of parts that make up a supply chain) and dynamic complexity (the unpredictability of a system's response to given inputs). They found that several forms of complexity-including upstream complexity, internal manufacturing complexity, and downstream complexity — can all negatively impact plant performance. Further, individual firms must assess the optimal degree of complexity. Bhamu and Sangwan [19] found that simultaneous adoption of leanness by both the manufacturer and the supply chain is critical to overall lean manufacturing implementation. Similarly, Miller et al. [45] found that lean concepts could successfully be applied to both manufacturing processes and supply chain optimization within a small furniture company.

In recent research, Um [21] found that, among highly customized manufacturers (approximately 11 percent of the sample were wood products companies), supply chain agility was not associated with business performance directly; actually it was negatively related. The author cited the costs associated with developing supply chain agility, including set-up and investment costs [20] as well as the operational costs of using small batches [47] to respond to customer requirement, as contributing to this negative direct relationship. However, improved customer service and product differentiation capability were both positively associated with supply chain agility, and both also led to higher business performance. In this study [21], the supply chain agility construct was comprised of 7 items, including the ability to rapidly: reduce the product development cycle time, reduce manufacturing lead time, increase the level of product customization, improve the level of customer service, improve delivery reliability, improve responsiveness to changing market needs, and reduce delivery lead time.

So how can supply chain agility be achieved? In a high customization environment, the key is in variety management [79]. Interestingly, the elements of variety management bring us back to previously discussed topics. Internal to the firm, variety management includes modularity $[8,13,68]$, cellular manufacturing $[45,49]$, and postponement of customer involvement in customization decisions (sometimes called the decoupling point) to latter stages of production. Examples of this strategy can be seen in the Amish furniture model described previously [60] and the U.S. upholstery industry, where imported components can be received as unfinished "white wood" and customized finishing and upholstery features are added at regional hubs closer to consumers [55,74]. Research based on a cross-section of Australian manufacturers found that firms in the Lumber and wood products category (SIC 24) and the Furniture and fixtures category (SIC 25) were not appreciably different than several other broad manufacturing categories on a measure of supply chain flexibility, although some of the lumber and wood products firms were among the highest scorers [75]. 
External to the firm, factors such as close customer relationships and collaboration with upstream and downstream partners are crucial to variety management [79]. Numerous studies have pointed to the importance of strong linkages between producers and customers as an integral part of supply chains. Lefaix-Durand et al. [80] examined the construct of "relationship value" and its potential to help suppliers create value in their customer relationships, which in turn can improve competitive advantage. They studied a specific example of the Canadian wood products industry supplying U.S. customers. They also developed a framework for differentiating customer relationships as "questionable", "supportive", "promising", or "strategic". These findings could have implications for not only wood products producers, but other business sectors as well. Parhizkar et al. [81] compared competitive factors for small- and medium-sized forest products firms. They found that export firms differed with regard to transportation methods, marketing activities, and production profiles compared to non-exporting hardwood lumber manufacturers. Exporting firms were also significantly larger in production and employment. They point to the importance of firms developing customer relationships in order to seek new markets in a global economy.

More complex supply chains are also possible. Collin et al. [82] suggest that alternative supply chain configurations can be customized to consumer demands. In their example (i.e., the telecommunications industry), a leading supplier deployed 3 different supply chains to meet 3 different customer demand chains. However, they point out that when supply chain design is too specialized, product backlogs may result, along with the potential for "inventory creep" and product obsolescence. Although these outcomes are less likely in the secondary hardwood industry, the principle of matching supply chains to unique customer demands could be considered for specialized products. Um's [79] research confirmed the predicted relationship that variety management, partnerships with suppliers, and closeness to customers were positively related to supply chain agility and flexibility. The implication is that supply chains can be managed (internally and externally) in high customization environments such that even though more complicated, the net benefits of customization can be achieved.

\section{Greening of the Supply Chain}

Bildsten et al. [62] posit that purchasing strategy is central to lean management. They discuss the contrasts between market-driven purchasing and value-driven purchasing. The former is characterized by buying in large quantities (and subsequently large inventory costs), mostly based on price, with frequent switching of suppliers over time. Value-driven purchasing, on the other hand, is based on close collaboration with a sole supplier who understands the technical aspects of the buyer's products, leading to just-in-time delivery, zero defects, and customized products. In a case study, Bildsten et al. [62] show that value-driven purchasing of kitchen cabinets by an industrialized housing construction company could possibly lead to a reduction in the costs, complexity, and time associated with installation of bulk-purchased cabinets in the company's modularized production process. Hughes et al. [83] considered modern supply chain management techniques and supply chain modeling, reviewing over 150 papers. However, only three papers addressed demand-driven modeling approaches to value/supply chains in the wood pellets sector.

Related to purchasing strategy is the notion of "lean and green" supply chains. Hardwood products firms can incorporate multiple objectives into their supply and value chains. A leading option on the "frontier" is the combination of agile supply chains with those that are focused on sustainability. Carvalho et al. [84] evaluated supply chains that had both "lean" and "green" paradigms. Their work is distinguished from past research in that "lean and green" aspects are considered jointly within proposed models. A set of lean and green management practices are proposed to enhance the operational, economic, and environmental performance of supply chains. Although lean and green paradigms share common goals, the primary distinction is that lean paradigms seek to minimize waste while green paradigms seek to minimize environmental impacts. 
Chavez et al. [85] studied "green" supply chains in the context of comparing antecedent factors (for example, customer demands and pressures) with outcome factors (for example, operational performance and customer satisfaction). Surveying 126 manufacturers, the authors found that customer pressure can lead to operational improvements such as flexibility, delivery, product quality, and cost. Of these factors, product quality and delivery aspects are most strongly associated with customer satisfaction. Although customer-centric considerations are important, this study noted that other stakeholders-for example, regulatory stakeholders and community stakeholders-are also able to exert influence on firms with regard to environmental performance. Cohen and Kozak [71] also considered the environmental performance of small- to medium-sized wood products firms in terms of their value chains. They furthered their focus on secondary (value-added) manufacturers. Their research highlighted influential points in the value chain that could be leveraged to create environmental behavior changes.

It is clear that the natures of various types of supply chains are changing quickly, with factors like globalization, green supply chains, and agility in supply chain design all influencing the ultimate goal of businesses-profitably serving customers. This has important ramifications for hardwood lumber firms that are competing in this ever-changing business environment. For example, Espinoza et al. [86] found that hardwood sawmills and distributors were providing more product-related services in recent years in response to increasing customer demands, including quicker delivery, just-in-time orders, certified products, and more lumber sorting for color and width. The numerous certification programs that currently exist for forest management and manufacturing processes can provide opportunities for companies to leverage green-compliant performance in their product promotion.

\section{Conclusions}

Today's economy calls for increasing customization of products to meet consumers' increasing demands for product variety. In locations worldwide where cost factors of production are high and a cost leadership strategy is difficult, this trend provides considerable opportunity for competitiveness. A synthesis of the literature regarding customization and several related concepts reveals that a move toward customization by companies requires a combination of technology investment, training, and management insight to be successful. Furthermore, technology investments and strategy development must match within a given company to move towards successful customized production. A key link is the supply chain, where companies can leverage both internal and external factors to enhance their competitiveness through agility and customization. Such agility and lean principles are critical to shortening lead times for consumers to receive their customized products, and the advantages of producing and sourcing locally also can be leveraged by domestic manufacturers. To date in the United States, the wood kitchen cabinet industry generally has followed the mass customization model more closely than the wood household furniture industry, and subsequently performed better in terms of maintaining domestic market share.

Although lean implementation can be difficult for smaller firms, many of the supply chain efficiencies necessary for successful customization can be found in economic clusters. In such clusters, specialization develops among many small shops and well-defined supply chains, a result that allows for flexibility among the shops. Proximity also can enhance communication and knowledge exchange among producers and customers. A good example is the Amish furniture manufacturing clusters located in Ohio and elsewhere, as well as clusters in parts of Europe.

Once models of modularized customization are developed, consumers can configure their desired products and manufacturers can then build to order. This model can open the door for new beneficial product innovations, such as use of character-marked wood in products. Implementation of this practice has long been sought by researchers and practitioners alike, and has started to become reality in some customized furniture lines where consumers can choose this product feature if desired. A related trend appears to be the "greening" of the supply chain. Green supply chain management has been found to influence not only environmental performance but also operational performance and 
economic performance [87]. The most important link in the supply chain-consumers—will be the ultimate determinant of how widely sustainability measures are accepted.

A culture of customization will require changes throughout the hardwood supply chain. At each value-added step, firms will need to determine what their customers need and then profitably deliver products and services that meet those needs. Recent research has shown that this is already beginning to occur with hardwood sawmills, which have increased the product services they are offering to customers as downstream manufacturers seek to become leaner and more customized. This synthesis has shown that there is no one strategy to universally adopt, but elements of competitiveness are apparent in several existing models and research findings that can be adapted by individual firms to help them be more competitive.

Author Contributions: Bumgardner and Nicholls jointly conceived of this synthesis paper. Bumgardner researched and wrote sections on competition, lean management, and clusters. Nicholls researched and wrote sections on supply chain management and greening the supply chain. Both authors collaborated on locating key reference papers, writing the Introduction, and writing the Conclusions.

Conflicts of Interest: The authors have no conflicts of interest to report.

\section{References}

1. Porter, M.E. Location, competition, and economic development: Local clusters in a global economy. Econ. Dev. Q. 2000, 14, 15-34. [CrossRef]

2. Wiedenbeck, J.; Wiemann, M.; Alderman, D.; Baumgras, J.; Luppold, W. Defining Hardwood Veneer Log Quality Attributes; General Technical Report NE-313; USDA Forest Service, Northeastern Research Station: Newtown Square, PA, USA, 2004.

3. Cassens, D.L. Factors Affecting the Quality of Timber for Face Veneer; Cooperative Extension Service FNR-127; Purdue University: West Lafayette, IN, USA, 1992.

4. Winistorfer, P.M. Competitiveness, manufacturing, and the role of education in the supply chain for the forest industry. For. Prod. J. 2005, 55, 6-16.

5. Bumgardner, M.; Buehlmann, U.; Espinoza, O. U.S. secondary wood manufacturers are becoming larger-Are there implications for hardwood sawmills? In Proceedings of the 6th International Scientific Conference on Hardwood Processing (ISCHP 17), Lahti, Finland, 25-28 September 2017; Möttönen, V., Heinonen, E., Eds.; Natural Resources Institute of Finland: Helsinki, Finland, 2017; pp. 91-96.

6. Panwar, R.; Vlosky, R.; Hansen, E. Gaining competitive advantage in the new normal. For. Prod. J. 2012, 62, 420-428. [CrossRef]

7. Brown, S.; Blackmon, K. Aligning manufacturing strategy and business-level competitive strategy in new competitive environments: The case for strategic resonance. J. Manag. Stud. 2005, 42, 794-815. [CrossRef]

8. Stump, B.; Badurdeen, F. Integrating lean and other strategies for mass customization manufacturing: A case study. J. Intell. Manuf. 2012, 23, 109-124. [CrossRef]

9. Jiao, J.; Ma, Q.; Tseng, M.M. Towards high value-added products and services: Mass customization and beyond. Technovation 2003, 23, 809-821. [CrossRef]

10. Song, M.; Gazo, R. Competitiveness of US household and office furniture industry. Int. J. Econ. Manag. Eng. 2013, 3, 47-55.

11. Schuler, A.; Buehlmann, U. Identifying Future Competitive Business Strategies for the U.S. Residential Wood Furniture Industry: Benchmarking and Paradigm Shifts; General Technical Report GTR-NE-304; USDA Forest Service, Northeastern Research Station: Newtown Square, PA, USA, 2003.

12. Dugan, M.K. The Furniture Wars: How America Lost a Fifty Billion Dollar Industry; Goosepen Press: Conover, NC, USA, 2009.

13. Azouzi, R.; Beauregard, R.; D'Amours, S. Exploratory case studies on manufacturing agility in the furniture industry. Manag. Res. News 2009, 32, 424-439. [CrossRef]

14. Pine, B.J. Mass Customization: The New Frontier in Business Competition; Harvard Business School Press: Boston, MA, USA, 1993.

15. Gilmore, J.H.; Pine, B.J. The four faces of mass customization. Harv. Bus. Rev. 1997, 75, 91-101. [PubMed] 
16. Mishra, R.; Pundir, A.K.; Ganapathy, L. Manufacturing flexibility research: A review of literature and agenda for future research. Glob. J. Flex. Syst. Manag. 2014, 15, 101-112. [CrossRef]

17. Fogliatto, F.S.; da Silveira, G.J.C.; Borenstein, D. The mass customization decade: An updated review of the literature. Int. J. Prod. Econ. 2012, 138, 14-25. [CrossRef]

18. Munsell, J.F.; Ares, A.; Barrett, S.M.; Bond, B.H.; Gagnon, J.L. Forest certification perspectives in the wood products supply chain in Virginia, USA. Forests 2017, 8, 364. [CrossRef]

19. Bhamu, J.; Sangwan, K.S. Lean manufacturing: Literature review and research issues. Int. J. Oper. Prod. Manag. 2014, 34, 876-940. [CrossRef]

20. Azouzi, R.; Beauregard, R.; D'Amours, S. An agility reference model for the furniture enterprise of the future. In Proceedings of the 7th Congress International de Genie Industriel, Trois-Rivieres, QC, Canada, 5-8 June 2007.

21. Um, J. The impact of supply chain agility on business performance in a high level customization environment. Oper. Manag. Res. 2017, 10, 10-19. [CrossRef]

22. Routroy, S.; Shankar, A. Performance analysis of agile supply chain. Int. J. Manuf. Technol. Manag. 2015, 29, 180-210. [CrossRef]

23. Grushecky, S.T.; Buehlmann, U.; Schuler, A.; Luppold, W.; Cesa, E. Decline in the U.S. furniture industry: A case study of the impacts to the hardwood lumber supply chain. Wood Fiber Sci. 2006, 38, 365-376.

24. Lihra, T.; Buehlmann, U.; Beauregard, R. Mass customization of wood furniture as a competitive strategy. Int. J. Mass Cust. 2008, 2, 200-214. [CrossRef]

25. Cumbo, D.; Kline, D.E.; Bumgardner, M.S. Benchmarking performance measurement and lean manufacturing in the rough mill. For. Prod. J. 2006, 56, 25-30.

26. Luppold, W.G.; Bumgardner, M.S. The wood household furniture and kitchen cabinet industries: A contrast in fortune. For. Prod. J. 2009, 59, 93-99. [CrossRef]

27. Buehlmann, U.; Schuler, A. The US household furniture industry: Status and opportunities. For. Prod. J. 2009, $59,20-28$.

28. Jones, M. Bulletin of Hardwood Market Statistics: 2013; Research Note FPL-RN-0337; USDA Forest Service, Forest Products Laboratory: Madison, WI, USA, 2016.

29. International Trade Administration. Trade Policy Information System (TPIS). Available online: http://tpis1. trade.gov/cgi-bin/wtpis/prod/tpis.cgi (accessed on 13 February 2018).

30. U.S. Census Bureau. 2014 Annual Survey of Manufactures-Tables. Available online: https://www.census. gov / data/tables/2014/econ/asm/2014-asm.html (accessed on 13 February 2018).

31. Al-Zu'bi, Z.M.F. Examining the impact of lean practices on flexibility performance: The moderating effect of environmental dynamism. Eng. Manag. Res. 2015, 4, 54-69. [CrossRef]

32. Womack, J.P.; Jones, D.T.; Roos, D. The Machine That Changed the World; Free Press: New York, NY, USA, 1990.

33. Shah, R.; Ward, P.T. Defining and developing measures of lean production. J. Oper. Manag. 2007, 25, 785-805. [CrossRef]

34. Olhager, J.; Prajogo, D. The impact of manufacturing and supply chain improvement initiatives: A survey comparing make-to-order and make-to-stock firms. Omega 2012, 40, 159-165. [CrossRef]

35. Nag, B.; Han, C.; Yao, D.-Q. Mapping supply chain strategy: An industry analysis. J. Manuf. Technol. Manag. 2014, 25, 351-370. [CrossRef]

36. Stavrulaki, E.; Davis, M. Aligning products with supply chain processes and strategy. Int. J. Logist. Manag. 2010, 21, 127-151. [CrossRef]

37. Ray, C.D.; Zuo, X.; Michael, J.H.; Wiedenbeck, J.K. The lean index: Operational "lean" metrics for the wood products industry. Wood Fiber Sci. 2006, 38, 238-255.

38. Haartveit, E.Y.; Kozak, R.A.; Maness, T.C. Supply chain management mapping for the forest products industry: Three cases from western Canada. J. For. Prod. Bus. Res. 2004, 1, 32.

39. Alves, A.C.; Dinis-Carvalho, J.; Sousa, R.M. Lean production as promoter of thinkers to achieve companies' agility. Learn. Organ. 2012, 19, 219-237. [CrossRef]

40. Thomas, R.E. Prioritizing parts from cutting bills when gang-ripping first. For. Prod. J. 1996, 46, 61-66.

41. Pirraglia, A.; Saloni, D.; van Dyk, H. Status of lean manufacturing implementation on secondary wood industries including residential, cabinet, millwork, and panel markets. BioResources 2009, 4, 1341-1358.

42. Czabke, J.; Hansen, E.N.; Doolen, T.L. A multisite field study of lean thinking in U.S. and German secondary wood products manufacturers. For. Prod. J. 2008, 58, 77-85. 
43. Ariss, S.S.; Zhang, Q. The impact of flexible process capability on the product-process matrix: An empirical investigation. Int. J. Prod. Econ. 2002, 76, 135-145. [CrossRef]

44. Buehlmann, U.; Bumgardner, M.; Alderman, D. Recent developments in US hardwood lumber markets and linkages to housing construction. Curr. For. Rep. 2017, 3, 213-222. [CrossRef]

45. Miller, G.; Pawloski, J.; Standridge, C. A case study of lean, sustainable manufacturing. J. Ind. Eng. Manag. 2010, 3, 11-32.

46. Buehlmann, U.; Bumgardner, M.; Sperber, M. How small firms contrast with large firms regarding perceptions, practices, and needs in the U.S. secondary woodworking industry. BioResources 2013, 8, 2669-2680. [CrossRef]

47. Yao, A.C.; Carlson, J.G.H. Agility and mixed-model furniture production. Int. J. Prod. Econ. 2003, 81-82, 95-102. [CrossRef]

48. Espinoza, O.; Bond, B.H.; Kline, E. Supply chain measures of performance for wood products manufacturing. For. Prod. J. 2010, 60, 700-708. [CrossRef]

49. Hunter, S.L.; Bullard, S.; Steele, P.H. Lean production in the furniture industry: The double D assembly cell. For. Prod. J. 2004, 54, 32-38.

50. Andersch, A.; Buehlmann, U.; Wiedenbeck, J.; Lawser, S. Status and opportunities associated with product costing strategies in wood component manufacturing. For. Sci. 2013, 59, 623-636. [CrossRef]

51. Porter, M.E. Clusters and the new economics of competition. Harv. Bus. Rev. 1998, 76, 77-90. [PubMed]

52. Economist. Clustering. 2009. Available online: http://www.economist.com/node/14292202 (accessed on 22 February 2018).

53. Aguilar, F.X.; Bratkovich, S.M.; Fernholz, K.; Garrard, A.; Grala, R.; Leightley, L.; Martin, W.; Munn, I.A. The Status of and Opportunities for Business Clustering within the Forest Products Sector in the U.S.; Full Report; US Endowment for Forestry and Communities, Inc.: Greenville, SC, USA, 2009.

54. Braden, R.; Fossum, H.; Eastin, I.; Dirks, J.; Lowell, E. The Role of Manufacturing Clusters in the Pacific Northwest Forest Products Industry; Working Paper 66; CINTRAFOR: Seattle, WA, USA, 1998.

55. Walcott, S.M. The furniture foothills and the spatial fix: Globalization in the furniture industry. Southeast. Geogr. 2011, 51, 6-30. [CrossRef]

56. Kodzi, E.T.; Gazo, R. A model for operational mass customization based recent studies in furniture manufacturing. In Proceedings of the 2007 World Conference on Mass Customization \& Personalization (MCP), Cambridge, MA, USA, 7-10 October 2007.

57. Buehlmann, U.; Schuler, A. Markets and market forces for secondary wood products. In The Global Forest Sector: Changes, Practices, and Prospects; Hansen, E., Panwar, R., Vlosky, R., Eds.; CRC Press: Boca Raton, FL, USA, 2014; pp. 77-98.

58. Luppold, W.G.; Bumgardner, M.S. Thirty-nine years of U.S. wood furniture importing: Sources and products. BioResources 2011, 6, 4895-4908.

59. Mottiar, Z.; Ingle, S. Broadening the entrepreneurial perspective: Interpreneurship in an Irish furniture region. Int. Small Bus. J. 2007, 25, 667-680. [CrossRef]

60. Bumgardner, M.S.; Graham, G.W.; Goebel, P.C.; Romig, R.L. How clustering dynamics influence lumber utilization patterns in the Amish-based furniture industry in Ohio. J. For. 2011, 109, 74-81.

61. Brookfield, J. Firm clustering and specialization: A study of Taiwan's machine tool industry. Small Bus. Econ. 2008, 30, 405-422. [CrossRef]

62. Bildsten, L.; Bjornfot, A.; Sandberg, E. Value-driven purchasing of kitchen cabinets in industrialised housing. J. Financ. Manag. Prop. Constr. 2011, 16, 73-83. [CrossRef]

63. Maskell, P. Low-tech competitive advantages and the role of proximity: The Danish wooden furniture industry. Eur. Urban Reg. Stud. 1998, 5, 99-118. [CrossRef]

64. Brinberg, D.; Bumgardner, M.; Daniloski, K. Understanding perception of wood household furniture: Application of a policy capturing approach. For. Prod. J. 2007, 57, 21-26.

65. Bumgardner, M.; Nicholls, D.; Barber, V. Character-marked furniture made from red alder harvested in southeast Alaska: Product perspectives from consumers and retailers. Can. J. For. Res. 2009, 39, 2450-2459. [CrossRef]

66. Leopold, A. The home builder conserves. Am. For. 1928, 34, 276-278, 297.

67. Bumgardner, M.S.; Bush, R.J.; West, C.D. Beyond yield improvement: Selected marketing aspects of character-marked furniture. For. Prod. J. 2000, 50, 51-58. 
68. Jensen, P.; Hamon, E.; Olofsson, T. Product development through lean design and modularization principles. In Proceedings of the 17th Annual Conference of the International Group for Lean Construction, Taipei, Taiwan, 15-17 July 2009; pp. 465-474.

69. Hock Soon, Q.; Udin, Z.-H. Supply chain management from the perspective of value chain flexibility: An exploratory study. J. Manuf. Technol. Manag. 2011, 22, 506-526. [CrossRef]

70. Christensen, W.J.; Germain, R.; Birou, L. Build-to-order and just-in-time as predictors of applied supply chain knowledge and market performance. J. Oper. Manag. 2005, 23, 470-481. [CrossRef]

71. Cohen, D.; Kozak, R. Mapping the Value Chain of SMEs in the Forest Products Industry; Report Prepared for Environment Canada and the Canadian Forest Service: Ottawa, ON, Canada, 2006.

72. Li, S.; Ragu-Nathan, B.; Ragu-Nathan, T.S.; Rao, S.S. The impact of supply chain management practices on competitive advantage and organizational performance. Omega 2006, 34, 107-124. [CrossRef]

73. Kisperska-Moron, D.; Swierczek, A. The selected determinants of manufacturing postponement within supply chain context: An international study. Int. J. Prod. Econ. 2011, 133, 192-200. [CrossRef]

74. Eksioglu, B.; Eksioglu, S.; Zhang, J.; Jin, M. A simulation model to analyze the impact of outsourcing on furniture supply chain performance. For. Prod. J. 2010, 60, 258-265. [CrossRef]

75. Jeeva, A.; Dickie, C. Theory and practice of procurement flexibility: A model for suppliers and manufacturers. J. Contemp. Issues Bus. Gov. 2009, 15, 59-79.

76. Ouhimmou, M.; D'Amours, S.; Beauregard, R.; Ait-Kadi, D.; Chauhan, S.S. Furniture supply chain tactical planning optimization using a time decomposition approach. Eur. J. Oper. Res. 2008, 189, 952-970. [CrossRef]

77. Shahi, S.; Pulkki, R. Supply chain network optimization of the Canadian forest products industry: A critical review. Am. J. Ind. Bus. Manag. 2013, 3, 631-643. [CrossRef]

78. Bozarth, C.C.; Warsing, D.P.; Flynn, B.B.; Flynn, E.J. The impact of supply chain complexity on manufacturing plant performance. J. Oper. Manag. 2009, 27, 78-93. [CrossRef]

79. Um, J. Improving supply chain flexibility and agility through variety management. Int. J. Logist. Manag. 2017, 28, 464-487.

80. Lefaix-Durand, A.; Kozak, R.; Beauregard, R.; Poulin, D. Extending relationship value: Observations from a case study of the Canadian structural wood products industry. J. Bus. Ind. Mark. 2009, 24, 389-407. [CrossRef]

81. Parhizkar, O.; Smith, R.; Miller, C. Comparison of important competitiveness factors for small- to medium-sized forest enterprises. For. Prod. J. 2009, 59, 81-86.

82. Collin, J.; Eloranta, E.; Holmström, J. How to design the right supply chains for your customers. Supply Chain Manag. Int. J. 2009, 14, 411-417.

83. Hughes, N.M.; Shahi, C.; Pulkki, R. A review of the wood pellet value chain, modern value/supply chain management approaches, and value/supply chain models. J. Renew. Energy 2014, 2014, 1-14.

84. Carvalho, H.; Azevedo, S.G.; Cruz-Machado, V. Supply chain performance management: Lean and green paradigms. Int. J. Bus. Perform. Supply Chain Model. 2010, 2, 303-333. [CrossRef]

85. Chavez, R.; Yu, W.; Feng, M.; Wiengarten, F. The effect of customer-centric green supply chain management on operational performance and customer satisfaction. Bus. Strategy Environ. 2016, 25, 205-220. [CrossRef]

86. Espinoza, O.; Buehlmann, U.; Bumgardner, M.; Smith, R. Intermediaries in the U.S. hardwood lumber market: Comparing and contrasting sawmills and distributors. BioResources 2014, 9, 6527-6539. [CrossRef]

87. Green, K.W., Jr.; Zelbst, P.J.; Meacham, J.; Bhadauria, V.S. Green supply chain management practices: Impact on performance. Supply Chain Manag. Int. J. 2012, 17, 290-305. [CrossRef]

(C) 2018 by the authors. Licensee MDPI, Basel, Switzerland. This article is an open access article distributed under the terms and conditions of the Creative Commons Attribution (CC BY) license (http://creativecommons.org/licenses/by/4.0/). 